\title{
Some biological characteristics of the marbled crab, Pachygrapsus marmoratus in the southern Black Sea (Sinop, Turkey)
}

\author{
Cetin SUMER ${ }^{1}$, Hakan AKSU², Sefer CELIK ${ }^{1}$, and Serdar BEKTAS ${ }^{1}$
}

\begin{abstract}
The aim of the present study was to determine some biological characteristics of Pachygrapsus marmoratus in Sinop harbor, Black Sea, between July 2013 and June 2014. A total of 237 crabs, ranging from 20.12 to $50.92 \mathrm{~mm}$ in carapace width (CW) and 14.18 to $45.98 \mathrm{~mm}$ carapace length (CL) were collected monthly. Male:female ratio was found 1:0.1. The mean CW, CL, and weight (W) were determined as $39.70 \pm 0.42 \mathrm{~mm}, 35.43 \pm 0.35 \mathrm{~mm}$, $28.72 \pm 0.74 \mathrm{~g}$ for males and $35.09 \pm 1.50 \mathrm{~mm}, 31.56 \pm 1.28 \mathrm{~mm}$, $19.65 \pm 1.65 \mathrm{~g}$ for females, respectively. Correlation analyses were also conducted to reveal some size parameters relationships between males and females. The b values of $\mathrm{CW}$ and $\mathrm{W}$ for males and females were found 2.28 and 2.08, respectively. Negative allometric growth (Pauly's t-test, $\mathrm{P}<0.05$ ) was observed males and females of $P$. marmoratus.

The condition factor (CF) varied 30.94-72.31 with a mean 45.66 \pm 0.48 . The highest mean condition factor (48.03) was recorded in March and the lowest (41.50) in August.
\end{abstract}

Keywords - Pachygrapsus marmoratus, some biological characteristics, Sinop, Black Sea.

\section{INTRODUCTION}

$\mathrm{T}_{1}^{\mathrm{H}}$ HE marbled crab, Pachygrapsus marmoratus (Fabricius, 1787) is a semi terrestrial crab in the intertidal belt of rocky shores, on breakwaters, pier piles and similar habitats throughout the Mediterranean Sea, Black Sea and northeastern Atlantic from Brittany to Morocco including the Canary Islands, the Azores and Madeira [1]-[2]-[3].

The intertidal species are active during aerial phases, while they shelter themselves in refuges during high tide or avoid submersion by migrating away from the water's edge. Most of these species rely on internal clocks as well as on external stimuli to synchronize their periods of activity and their migrations with the tidal phases [4]-[5]-[6]-[7]. P. marmoratus has a flexible omnivorous diet with prey intake mainly being hard-shelled organisms such as limpets, barnacles and mussels, as well as algae [7]-[8].

P. marmoratus is dominant intertidal brachyuran on the rocky Black Sea shore of Turkey, and its habitat includes the whole intertidal zone [9]-[10]. There are limited biological information about the species in this region [11]-[12]. In the

\footnotetext{
${ }^{1}$ Sinop University, Faculty of Fisheries and Aquaculture, 57100, Sinop, TURKEY

${ }^{2}$ Sinop University Vocational Schools, Fisheries Department, 57000, Sinop, TURKEY
}

present study, we described the size composition, sex rates, length-weight relationships as carapace length and carapace weight of P. marmoratus on the Black Sea coasts of Sinop, Turkey.

\section{MATERIALS AND METHODS}

The marbled crabs were collected from Sinop harbor southern Black Sea between between July 2013 and June 2014. Marbled crabs were caught monthly by trammel nets (mesh sizes, 50-56-60-64 mm), from the depths raging 2 to 6 $\mathrm{m}$. Distinction of sex was made based on typical characteristics of the abdomen [13]. The carapace width (CW) was measured from the tip of the left dorsal spine to the tip of the right dorsal spine and carapace length (CL) was measured with a vernier caliper from the edge of the frontal region near the eye to the base of the carapace back wall [14].

The length-weight relationship $\mathrm{W}=\mathrm{a} \mathrm{L}^{\mathrm{b}}$ was applied female and male marbled crabs, where $\mathrm{W}$ is the weight (g), $\mathrm{L}$ is the total length (mm) (CW and CL), and a, b are constants [15]. The Pauly's t-test was used to test of the calculated $b$ values for females and males [16]. The significance of the regression (r) for the carapace width-weight data pairs was assessed by ANOVA, analyzed using ordinary least squares regression (95\% confidence). Sex ratio was analyzed using Chi-square test $(\chi 2)$. The condition factor $(\mathrm{CF})$ was calculated as $\mathrm{CF}=$ $\left(\mathrm{W} / \mathrm{L}^{3}\right) \times 100$ [17].

\section{RESULT AND DISCUSSION}

During the study, a total of 237 marbled crabs were collected, ranging between 20.12 to $50.92 \mathrm{~mm}$ in CW for males and 21.59 to $45.92 \mathrm{~mm}$ in CW for females, 14.18 to $45.98 \mathrm{~mm}$ CL for males and 20.34 to $40.32 \mathrm{~mm}$ CL for females. The mean CW and CL was found $39.70 \pm 0.42 \mathrm{~mm}$, $35.43 \pm 0.35 \mathrm{~mm}$ for males and $35.09 \pm 1.50 \mathrm{~mm}, 31.56 \pm 1.28$ $\mathrm{mm}$ for females, respectively. The total weights of marbled crabs were changed 3.92-52.22 $\mathrm{g}$ with a mean of $28.72 \pm 0.74 \mathrm{~g}$ for males and 5.45-36.19 $\mathrm{g}$ with a mean of $19.65 \pm 1.65 \mathrm{~g}$ for females. The mean CW and CL was significantly different for among males and males $(\mathrm{P}<0.05)$.

The sex ratio was estimated in favor of males 1:0.10 and the difference between the sexes was highly significant $\left(\chi_{2}=\right.$ 153.93; d.f. $=1 ; \mathrm{P}<0.05)$. Other studies gave to the sex ratio (Females:males) 1:1.27 in Trabzon coasts of Turkey [11] and 1:1 in Ordu coasts of Turkey [12]. 
The length-weight equation with $\mathrm{CW}$ was calculated $\mathrm{W}=0.0066 \mathrm{CW}^{2.2817}\left(\mathrm{r}^{2}=0.85\right)$ for males and $\mathrm{W}=0.0116 \mathrm{CW}$ $2.0818\left(r^{2}=0.91\right)$ for females (Fig. 1). Negative allometric growth (Pauly's t-test, $\mathrm{P}<0.05$ ) was observed for each of the sexes marbled crabs with $\mathrm{CW}$. The length-weight equation with CL was calculated $\mathrm{W}=0.0068 \mathrm{CL}{ }^{2.3373}\left(\mathrm{r}^{2}=0.85\right)$ for males and $\mathrm{W}=0.0054 \mathrm{CL}^{2.3717}\left(\mathrm{r}^{2}=0.96\right)$ for females (Fig. 1). Negative allometric growth (Pauly's t-test, $\mathrm{P}<0.05$ ) was observed for each of the sexes marbled crabs with CL. Other studies gave also the similar results for $\mathrm{b}$ values as females (2.63) and males (2.87) with CW in Trabzon coasts of Turkey [11] and for females individuals 2.963 with CL in Ordu coasts of Turkey [12]. Also positive allometric growth was gave for males $(b=3.035)$ with $C L$ and females $(b=3.103)$, males $(b=$ 3.065) individuals with CW [12]. The parameters of lengthweight relationship may be affected by various factors, such as period, temperature, food, environmental conditions, stomach fullness, differences in age, stage of maturity and sex [16].
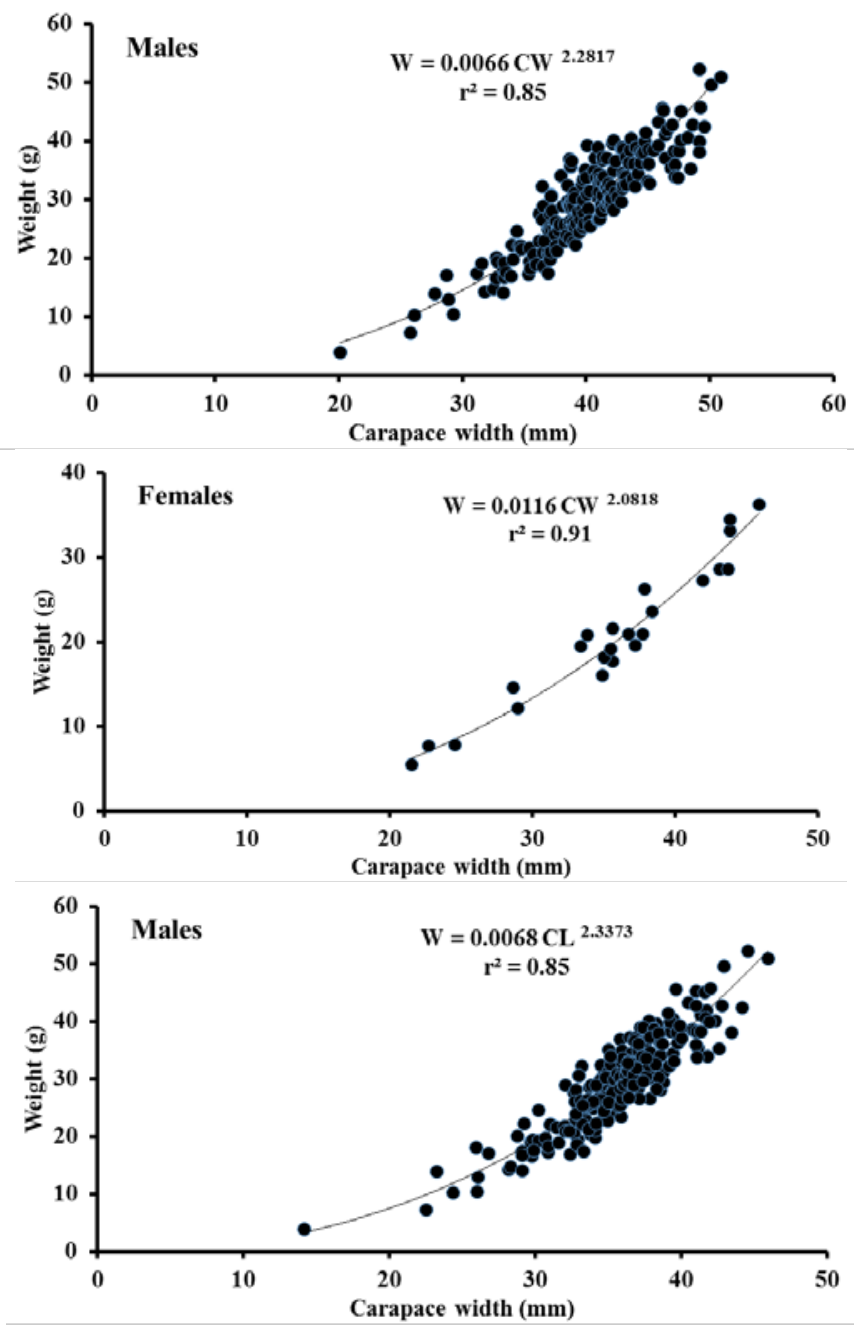

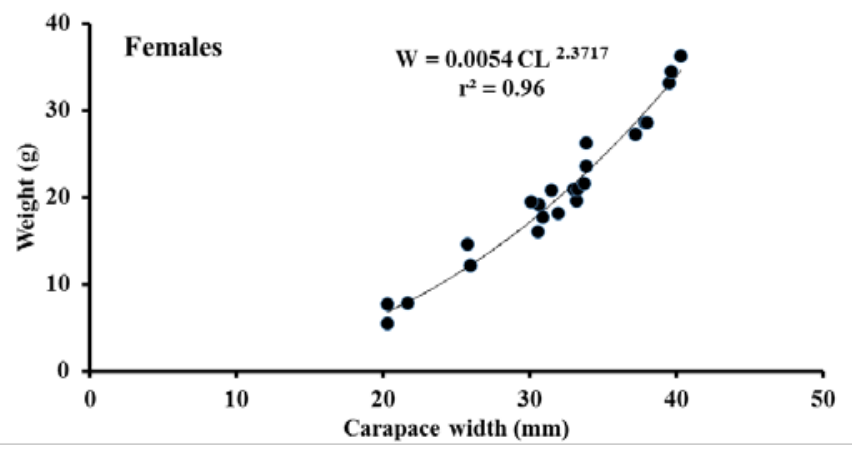

Fig. 1. Relationships between CW-W and CL-W for sexes

The relationships between carapace width and carapace length of marbled crabs was determined $\mathrm{CL}=$ $0.8456 * \mathrm{CW}+1.8389$ for males and $\mathrm{CL}=0.86 * \mathrm{CW}+1.1939$ for females (Fig. 2). The highest correlation coefficient was obtained between CW and CL in both sexes (Fig. 2). There were also strong correlations between $\mathrm{W}$ and CW-CL for females and males.
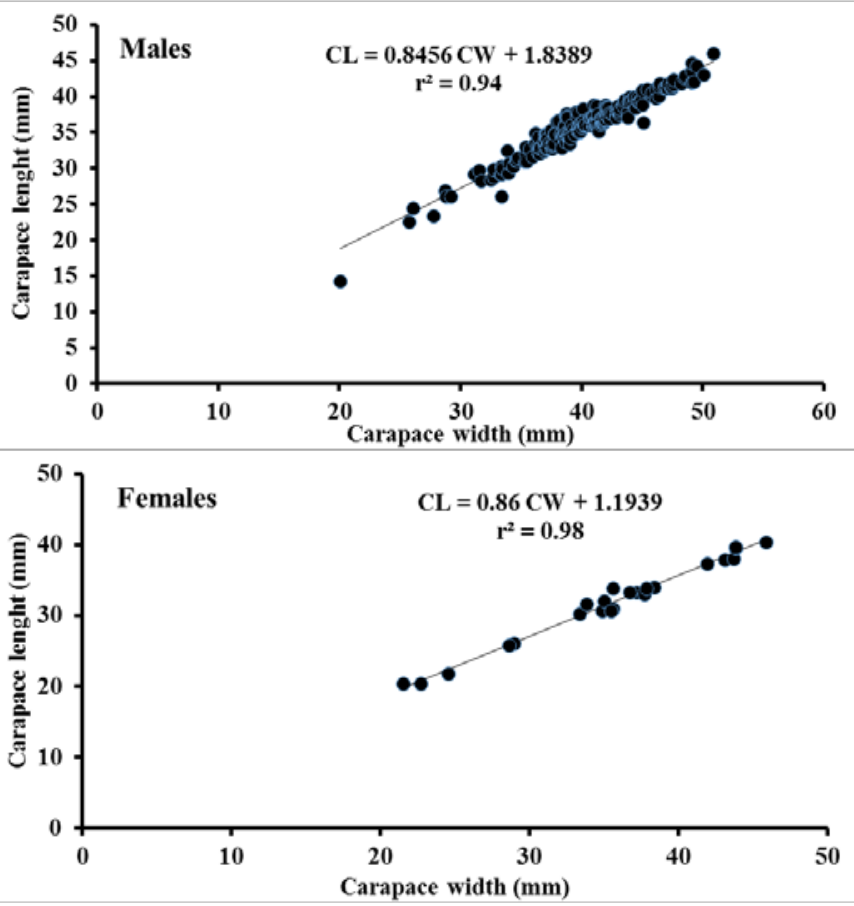

Fig. 2. The relationship between carapace width and carapace length of marbled crabs

Condition factor of marbled crabs ranged from 30.94 to 72.31 (with mean: $45.66 \pm 0.48$ ). The highest mean condition factor (48.03) was recorded in March and the lowest (41.50) in August. In Ordu coasts of Turkey [12], the mean condition factors were gave as 49.03 for males and 45.79 for females. The highest monthly condition index (56.42) was recorded in March for males and (42.09) in May for females. In our study, similar results were found for the highest average condition factor (March).

This is the first study about some biologic parameters of the marbled crabs population in Sinop on the southern coast of Black Sea. The findings of our study will constitute an important database for future studies of $P$. marmoratus and of other crab species. 


\section{ACKNOWLEDGMENT}

The authors thanks to Sinop University BAP Unit for their financial support (Project number: SÜF-1901-12-09).

\section{REFERENCES}

[1] R.W. Ingle, British Crabs. Oxford University Press and British Museum Natural History, London. 222 pp, 1980.

[2] Udekem d'Acoz C. d', "Inventaire et distribution des crustace's de'capodes de l'Atlantique nord-oriental, de la Me'diterranée et des eaux continentales adjacentes au nord de 258N," Patrimoines Naturels 40, 1-383, 1999.

[3] R.W. Ingle, and P.F. Clark, "First reported occurrences of the marbled crab, Pachygrapsus marmoratus (Crustacea: Barchyura: Grapsoidea) in southern coastal waters of the Bristish Isles," Journal of the Marine Biological Association 2-Biodiversity Records 5 pp. DOI: 10.1017/S1755267206002454, 2006. http://dx.doi.org/10.1017/S1755267206002454

[4] W. Seiple "The ecological significance of the locomotor activity rhythms of Sesarma cinereum (Bosc) and Sesarma reticulatum (Say)

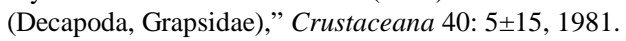

[5] J.D. Palmer, The biological rhythms and clocks of intertidal animals. Oxford University Press, Oxford, 1995.

[6] M. Vannini, S. Cannicci, and R.K. Ruwa "Effect of light intensity on vertical migrations of the tree crab Sesarma leptosome (Decapoda, Grapsidae)," J exp mar Biol Ecol 185: 181ะ189, 1995.

[7] S. Cannicci, M, Gomei, B. Boddi, and M. Vannini "Feeding habits and natural diet of the intertidal crab Pachygrapsus marmoratus: opportunistic browser or selective feeder?," Estuar Coast Shelf Sci. 54:983-1001, 2002.

[8] A. Silva, D. Boaventura, A. Flores, P. Re', and S.J. Hawkins, Rare predation by the intertidal crab Pachygrapsus marmoratus on the limpet Patella depressa. Journal of the Marine Biological Association of the United Kingdom 84, 367-370, 2004.

[9] S. Bilgin, and E.S. Celik, "The Crabs of the Sinop Coasts of the Black Sea (Turkey),” Sci. Eng. J Firat Univ., 16: 337-345, 2004.

[10] M. Aydin, U. Karadurmuş, and C. Mutlu, "The Crab Species of the Middle and East Black Sea (Turkey)," The Black Sea Journal of Sciences 3(9):1-16, [In Turkish.], 2013.

[11] A.Ş. Selimoğlu, "Determination of some bioecological characteristics of crab species Liocarcinus vernalis and Pachygrapsus marmoratus of Trabzon coasts. MSc thesis. Karadeniz Technical University, Turkey. [In Turkish.], 1997.

[12] M. Aydin, U. Karadurmuş, and E. Tunca, "Biological characteristics of Pachygrapsus marmoratus in the southern Black Sea (Turkey)," Journal of the Marine Biological Association of the United Kingdom, 94(7), 1441-1449, 2014.

http://dx.doi.org/10.1017/S0025315414000253

[13] E.L. Wenner, "Incidence of insemination in female blue crabs, Callinectes sapidus,” Journal of Crustacean Biology 9, 587-594, 1989.

[14] R. Muino, L. Fernandez, E. Gonzalez-Gurriaran, J. Freire, and J.A. Vilar, "Size at maturity of Liocarcinus depurator (Brachyura: Portunidae): a reproductive and morphometric study," Journal of the Marine Biological Association of the United Kingdom, 79, 295-303, 1999.

[15] W.E. Ricker, "Linear regressions in fishery research," Journal of the Fisheries Research Board of Canada 30, 409-434, 1973. http://dx.doi.org/10.1139/f73-072

[16] D. Pauly, "Fish Population Dynamics in Tropical Water: a manual for use with programme calculators" ICLARM Studies and Reviews 8.325 pp, 1984.

[17] T.B. Bagenal,. "Methods for Assessment of Fish Production in Fresh Waters," 3rd ed., IBM Handbook No:3, Blackwell Scientific Publication. 1978. 